

COMMUNICATIONS

EARTH\&ENMRONMENT

ARTICLE

https://doi.org/10.1038/s43247-020-00059-6 OPEN

\title{
Southward migration of the Southern Hemisphere westerly winds corresponds with warming climate over centennial timescales
}

Bianca B. Perren (1) ${ }^{1 凶}$, Dominic A. Hodgson ${ }^{1,2}$, Stephen J. Roberts ${ }^{1}$, Louise Sime (10 1, Wim Van Nieuwenhuyze ${ }^{3}$, Elie Verleyen (1) ${ }^{3} \&$ Wim Vyverman (1) ${ }^{3}$

Recent changes in the strength and location of the Southern Hemisphere westerly winds (SHW) have been linked to continental droughts and wildfires, changes in the Southern Ocean carbon sink, sea ice extent, ocean circulation, and ice shelf stability. Despite their critical role, our ability to predict their impacts under future climates is limited by a lack of data on SHW behaviour over centennial timescales. Here, we present a 700-year record of changes in SHW intensity from sub-Antarctic Marion Island using diatom and geochemical proxies and compare it with paleoclimate records and recent instrumental data. During cool periods, such as the Little Ice Age (c. 1400-1870 CE), the winds weakened and shifted towards the equator, and during warm periods they intensified and migrated poleward. These results imply that changes in the latitudinal temperature gradient drive century-scale SHW migrations, and that intensification of impacts can be anticipated in the coming century.

\footnotetext{
${ }^{1}$ British Antarctic Survey, High Cross, Madingley Road, Cambridge CB3 OET, UK. ${ }^{2}$ Department of Geography, University of Durham, Durham DH1 3LE, UK.

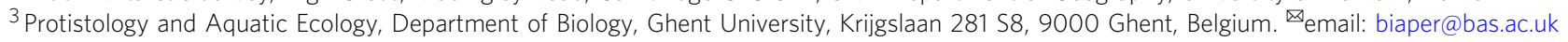


$\mathrm{R}$ ecent intensification and southward migration of the Southern Hemisphere westerly winds (SHW) have been implicated in a number of important physical changes in the southern high latitudes. These include: (1) changes to the Southern Ocean $\mathrm{CO}_{2}$ sink through alterations in ocean mixing ${ }^{1-3}$; (2) the loss of ice shelves fringing the West Antarctic Ice Sheet and Antarctic Peninsula ice sheets through enhanced basal melting ${ }^{4-8}$; (3) changes to Antarctic sea ice extent ${ }^{9}$; (4) enhanced Agulhas leakage ${ }^{10}$, and (5) warming along the Antarctic Peninsula ${ }^{11-13}$. Many of these changes have far-reaching implications for global climate, ocean circulation, and sea level rise.

Regionally, changes in the position and intensity of the core belt of the SHW (also identified by the Southern Annular Mode, SAM index ${ }^{14}$ ), have influenced precipitation patterns in southern continental landmasses ${ }^{15,16}$. Notably, the recent (post-1950 CE) southward (poleward) intensification of the SHW has shifted the main moisture-carrying storm tracks away from continental regions ${ }^{17}$. This has resulted in reduced precipitation in New Zealand $^{18,19}$ and droughts and wildfires in southwestern Australia $^{20}$, western South Africa ${ }^{21}$, and southern South America ${ }^{22,23}$, with their associated ecological and economic impacts ${ }^{24}$.

Despite the importance of the SHW, our current understanding of how they influence Southern Hemisphere climate on longer timescales is limited by the spatial and temporal patchiness of reconstructions in their core latitudes, coupled with few modelled simulations of their observed behaviour ${ }^{25-27}$. This is important because we are experiencing a continued net poleward migration and intensification of the SHW primarily as a result of loss of stratospheric ozone since the $1960 \mathrm{~s}^{28}$. While ozone recovery in the coming decades is expected to reverse these long term trends, especially in the austral spring-summer months, the increase in greenhouse gas-based climate warming may counteract this process, driving renewed poleward year-round intensification of the $\mathrm{SHW}^{29-31}$. However, the baseline natural variability of the SHW, without the added influence of ozone depletion, is not well-understood over longer timescales ${ }^{28}$. Paleoclimatic records of westerly wind behaviour can therefore help establish a framework for past SHW modalities, bridge the model-data gap, and better constrain the range of future climate change projections.

Although their distribution is increasing, past reconstructions of the SHW have been largely concentrated within Patagonia ${ }^{32-34}$ and to a lesser extent from the north of the core belt of the westerly winds on the continental landmasses ${ }^{35-37}$. Historically, reconstructions have typically relied on indirect proxies for assessing changing wind strength (e.g., changes in precipitation inferred from sub-fossil pollen assemblages, and sediment geochemistry, etc.). While several recent studies have sought to address these limitations ${ }^{38}$, there still remain few records of SHW variability from directly within their core belt. Here, we present a 700 -year record of SHW from the sediments of a small lake on the west coast of sub-Antarctic Marion Island $\left(46^{\circ} \mathrm{S}\right.$, Fig. 1, Supplementary Fig. 1), that lies on the northern margin of the SHW belt (Supplementary Fig. 2). Our reconstruction is based on tracking sea salt and minerogenic inputs using a combination of a diatom-based conductivity proxy and micro-X-ray fluorescence (XRF) measurements (see "Methods" section). We document coherent shifts in SHW intensity, which when compared with other regional records, we attribute to latitudinal shifts in the SHW linked to globally colder and warmer periods over the last 700 years.

\section{Results}

The sediment record recovered from Marion Island dates to $\sim 1300 \mathrm{CE}$ based on a model incorporating ${ }^{210} \mathrm{~Pb},{ }^{137} \mathrm{Cs}$ and ${ }^{14} \mathrm{C}$ analyses (see "Methods" section and Supplementary Methods, Supplementary Figs. 8, 9).

Changes in sea salt aerosol deposition were tracked by shifts in sub-fossil diatom species assemblages in the sediments. These respond to changes in lake water conductivity resulting from past sea salt aerosol delivery ${ }^{39}$. A weighted averaging statistical model to reconstruct past conductivity was based on measuring the present relationship between modern diatom species assemblages and lake water conductivity in 64 lakes on the island ${ }^{40}$ (see Supplementary Methods). These changes are also tracked by a Principle Components Analysis (PCA) of the downcore samples. The second axis, which explains $14 \%$ of the variance, closely follows that of the diatom-inferred conductivity (Fig. 2).

Diatom species in the core shift from moss- and soil-associated taxa with higher salinity tolerance (e.g., Diadesmis spp.) at the beginning of the record, to taxa indicative of fresher water lakes and pools (e.g., Aulacoseira principissa and Psammothidium confusum) circa $1450 \mathrm{CE}$. Around $1920 \mathrm{CE}$, these taxa then give way to lake/pool diatoms that are associated with higher salinity conditions (e.g., Planothidium quadripunctatum and Karayevia oblongellum) (for discussion of diatom changes see Supplementary Note 2, Supplementary Fig. 10).

Three significant sea salt aerosol zones (I, II, III) are seen in the diatom-inferred conductivity: (III) a period of high DI conductivity between 1300 and $1450 \mathrm{CE}$, followed by (II) a lowconductivity interval from 1450-1920 CE and (I) after $1920 \mathrm{CE}$, a higher DI-conductivity period, reaching a maximum in the last century (c. $1950 \mathrm{CE}$ ) (Fig. 2).

To test this reconstruction, we also measured changes in minerogenic deposition using $\mu$-XRF. This method measures a combination of typically "sea-salt" derived aerosols (e.g., $\mathrm{Cl}$, $\mathrm{Br}^{41}$ ), wind-blown (dust) as well as "crustal" minerogenic elements (e.g. $\mathrm{Ti}, \mathrm{Al}, \mathrm{K}, \mathrm{Sr}, \mathrm{Fe}, \mathrm{Mn}^{41}$ ) together. We also measured $\mathrm{Fe}$ and other magnetic minerals using magnetic susceptibility. This "minerogenic signal" is captured by the PCA axis 1 (PC1; Fig. 2) which is dominated on the positive side by elements $\mathrm{Fe}, \mathrm{Ca}, \mathrm{Ti}, \mathrm{Sr}$, $\mathrm{K}, \mathrm{Mn}$. The negative side of the axis captures the more organic fraction, which is also tracked by the $\mathrm{C}, \mathrm{N}$, and $\delta^{13} \mathrm{C}$ measurements (for more information on geochemical changes see Supplementary Note 3, Supplementary Figs. 12, 13).

The minerogenic measurements ( $\mu$-XRF PC1) follow broadly similar trends to diatom-inferred conductivity (Fig. 2), with the highest values in the earliest part of the record and lower values between 1500 and $1800 \mathrm{CE}$. Two large amplitude changes between 1500 and $1650 \mathrm{CE}$ in the $\mu$-XRF PC1 plot (37\% of the variance) relate to two large visible basic tephra deposits, whose timing is stratigraphically consistent with other tephras on the island (unpublished data).

Our reconstruction of the SHW is also validated through comparison with the instrumental records of climate changes, such as local temperature, pressure, precipitation, the SHW jet latitude and the SAM index in recent decades (Fig. 3).

Combined, these sedimentary records of sea salt and minerogenic inputs document major changes in the strength of the SHW at Marion Island over the last 700 years. Of these large scale variations, three major features are apparent: (1) higher aerosol deposition and hence intensified SHW prior to $1450 \mathrm{CE}$ and from $1920 \mathrm{CE}$ to the present day, (2) lower aerosol deposition and hence reduced SHW between 1450 and $1920 \mathrm{CE}$, and (3) the highest inferred SHW (of the last 700-years) occurring within the last century (until $1950 \mathrm{CE}$ ).

\section{Discussion}

Differentiating a SHW signal from local factors. In order to confidently reconstruct SHW from lake sediments using both 


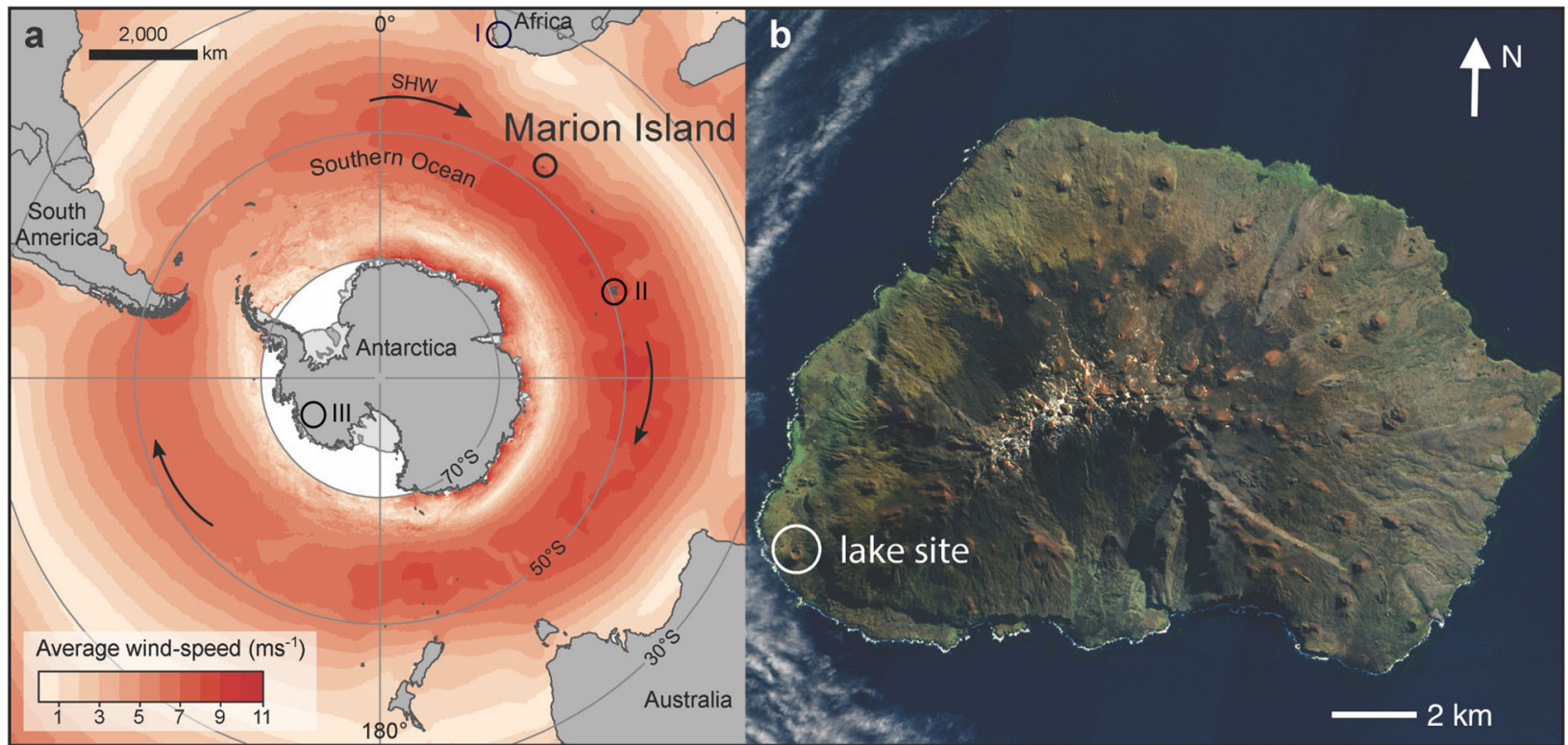

Fig. 1 Map showing location of Marion Island and study site. a Map showing location of Marion Island and the core belt of the Southern Hemisphere westerly winds. Arrows mark the direction of surface winds (see also Supplementary Fig. 3). Shaded annual sea surface-level (10 m) mean wind speeds are based on NOAA blended high resolution (0.25 degree grid) vector data downloaded from (https://www.ncdc.noaa.gov/data-access/marineocean-data/ blended-global/blended-sea-winds), $\mathbf{b}$ the location of the lake coring site at La Grange Kop on Marion Island (satellite imagery courtesy of NASA Visible Earth, https://visibleearth.nasa.gov/). Numbered sites indicate places referred to in the text: (I) Verlorenvlei, in the winter rainfall zone (WRZ) of South Africa50, (II) îles Kerguelen, (III) West Antarctic Ice Sheet (WAIS68).

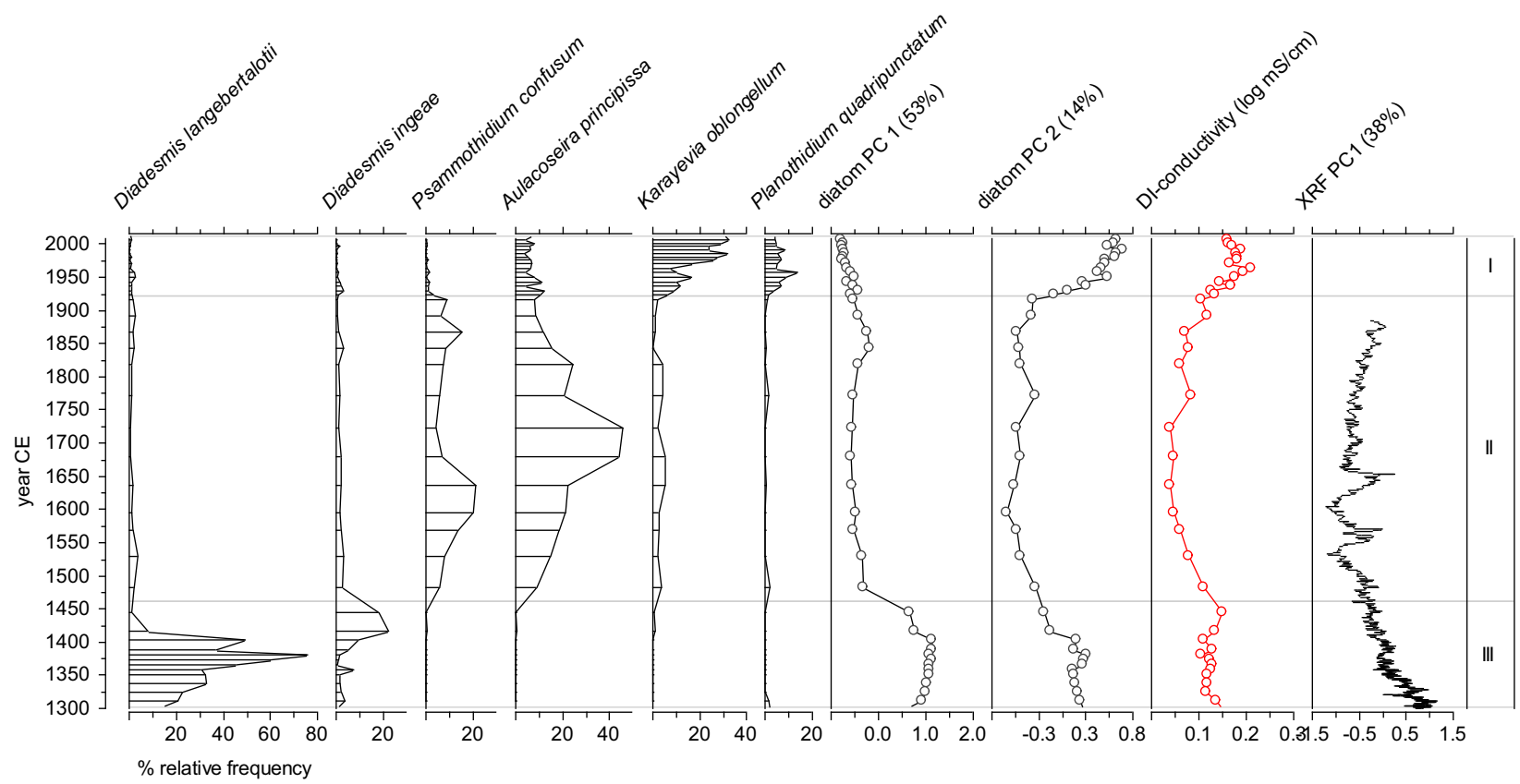

Fig. 2 Stratigraphic diagram of diatoms from Marion Island. Stratigraphic diagram of the relative frequency (\%) of the 6 most abundant diatom taxa, the principal components analysis first and second axes (PC1 and PC2), and the diatom-inferred conductivity (log mS cm ${ }^{-1}$ ) and $\mu$-XRF-scanning PC1 results from Marion Island. Biostratigraphic zone III (1300-1450 CE) is marked by the presence of soil- and moss-associated diatoms with a high salinity tolerance, a high PC2, DI-conductivity, and more minerogenic material. Zone II (1450-1920 CE) is defined by a shift to diatoms indicative of higher water levels and lower conductivity as well as lower PC2 and minerogenic material. Zone I (1920 CE-present) shows a shift towards species with higher salinity tolerances, higher PC2 and diatom-inferred conductivity. (Note that scanning-based geochemical data is only available below $10 \mathrm{~cm}$ ).

biological and geochemical techniques, it is necessary to disentangle the climate signal from local ecological and edaphic factors. In many lake systems, the relationship between precipitation and evaporation is the main driver of lakewater conductivity. However, on Marion Island, SHW are responsible for the delivery of saltspray to its western flanks and also the low-pressure systems which bring precipitation to the island. We can use the species assemblages to differentiate between lake level (habitat) and conductivity $^{42}$ (see Supplementary Note 2; Supplementary Fig. 11), and can reliably differentiate between deep water, 

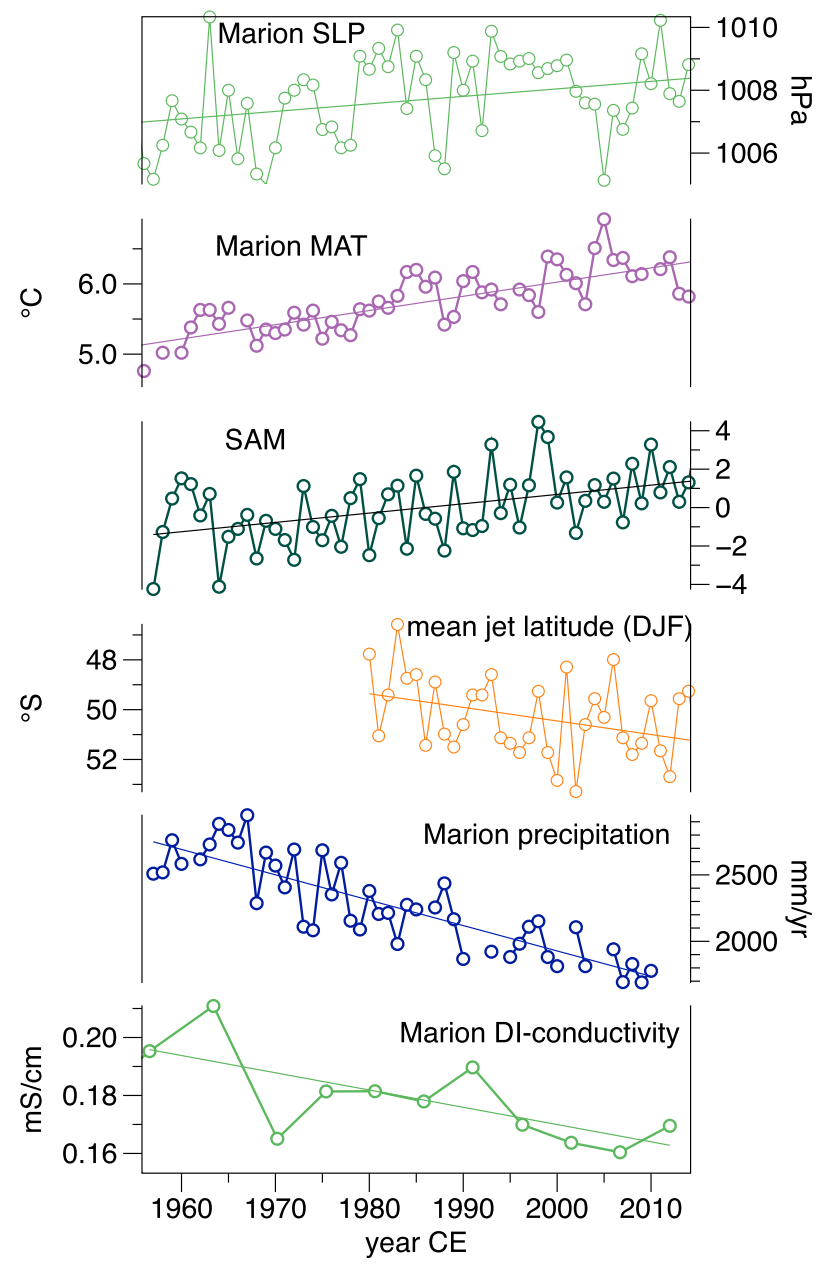

Fig. 3 Comparison of instrumental, satellite, and core data from Marion Is. Comparison of instrumental and satellite and modelling data since the 1950s, documenting the effects of a southward intensifying SHW on the island. This is shown by a rise in the Marion Island atmospheric pressure (SLP) and temperature ${ }^{91}$ along with the Marshall SAM index ${ }^{14}$, while the mean latitude of the summer (DJF) SH Jet declines ${ }^{64}$ along with the annual precipitation ${ }^{91}$ and the inferred wind strength record (as DI-conductivity) from Marion Island. Plotted lines are linear regressions.

freshwater periods (e.g., 1450-1920 CE) and deep water, more saline periods (1920 CE to the present), thereby mitigating any conflation of water balance-driven changes in conductivity and those that are SHW wind-derived. Since the 1950s, we can also see a clear decrease in precipitation and conductivity on Marion Island, suggesting that $\mathrm{P}-\mathrm{E}$ does not play a key role in conductivity at this site (Fig. 3). Additionally, the lake has a small catchment and is located on the windward side of the island, to reduce edaphic minerogenic factors that could overwhelm the climate signal.

Links between SHW and temperature. The Marion Island SHW reconstruction shows a long-term correspondence between SHW and temperature within the limitations of the record's temporal resolution. The period of lowest inferred-wind strength on Marion Island between 1450 and $1920 \mathrm{CE}$ is similar to the timing of regional declines in temperature associated with the Little Ice Age (LIA; c. 1400-1870 CE; Fig. 4). Globally, reconstructions place LIA temperatures $\sim 0.5^{\circ} \mathrm{C}$ cooler than the $1940-1990 \mathrm{~s}^{43,44}$, but regionally, these temperature changes were more pronounced with $0.75{ }^{\circ} \mathrm{C}$ change in Southern Hemisphere reconstructions ${ }^{45}$

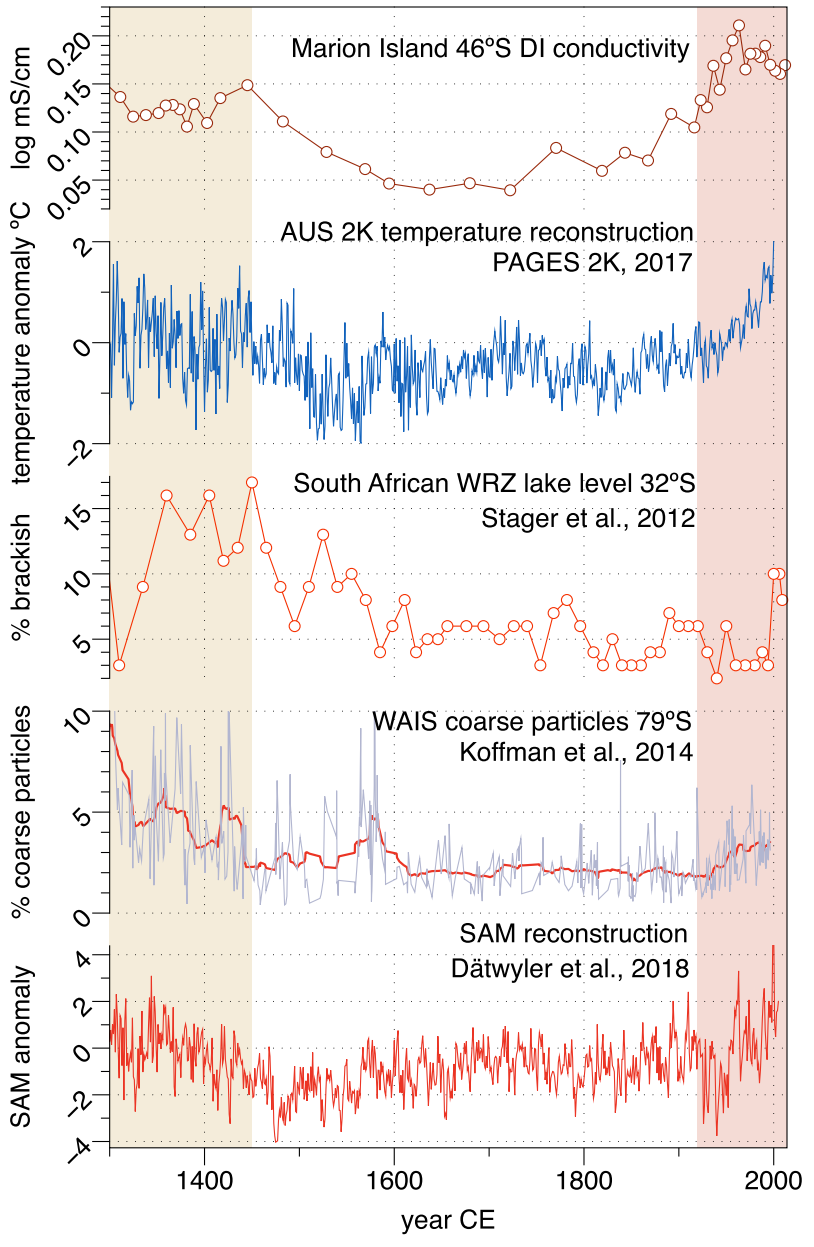

Fig. 4 Comparison of results from Marion Island with regional paleoclimate records. Comparison of Marion Island DI-conductivity results with the Australasian $2 \mathrm{~K}$ temperature reconstruction ${ }^{46}$, lake water level (salinity: \% brackish diatoms) from Verlorenvlei in the WRZ, South Africa ${ }^{50}$, the WAIS ice core coarse particle size ${ }^{68}$ (with a 20 pt running mean in red) and the SAM reconstruction ${ }^{92}$. Orange and pink bars represent warmer periods with stronger, more poleward-shifted SHW delineated by the Marion Island biostratigraphic zones I and III.

and up to $2{ }^{\circ} \mathrm{C}$ in the AUS2K reconstruction for Australasia over that same time period ${ }^{46}$. While the expression of a Southern Hemisphere Little Ice Age is spatially variable ${ }^{47}$, the majority of Southern Hemisphere extreme cold events occur between c. 1500 and $1700 \mathrm{CE}^{45}$. Conversely, at Marion Island, periods of higher inferred wind strength before $1450 \mathrm{CE}$ and from $1920 \mathrm{CE}$ onwards coincide with records of both global and regional warming (Fig. 4).

Links between SHW, temperature, and rainfall. Links between SHW, temperature and rainfall are well established in recent regional meterological $23,48,49$ and paleoclimate records ${ }^{32,33,50-52}$. While not universal (e.g. in NZ fjords ${ }^{36,37}$ ) or sustained (e.g., Patagonian glacier fluctuations ${ }^{53}$ ), cool periods, such as the LIA, have been associated with increased rainfall. For example, in Patagonia, many records show cooler and wetter conditions beginning around c. 1450-1500 CE, associated with increased effective precipitation recorded in lakes ${ }^{33,54-56}$ and glacier advances ${ }^{53,57}$. Colder and wetter conditions are also seen in New Zealand and Australia during the LIA ${ }^{58-60}$. Nearer to Marion Island, southwestern South African records also document an increase in rainfall during this time (c. 1350-1900 $\mathrm{CE}^{35,50}$ ). 
Conversely, during warmer periods rainfall has generally decreased, especially in the period after $1950 \mathrm{CE}$.

Meridional migration of the SHW. The relationship between the most recent part of the SHW reconstruction and the increasingly positive phase of SAM (Fig. 3) is consistent with a poleward displacement of the core belt of the westerlies ${ }^{49}$ (Fig. 3); where the core belt of the SHW has moved south of Marion Island, resulting in demonstrably weaker SHW at the latitudinal belt of Marion Island since the $1950 \mathrm{~s}^{48}$. This has resulted in a large increase $\left(\sim 1.5^{\circ} \mathrm{C}\right)$ in temperature at Marion Island ${ }^{48}$ (Fig. 3), consistent with other sub-Antarctic islands (see also Supplementary Fig. 4$)^{61}$ and the Antarctic Peninsula ${ }^{11}$ and with changes in the spatial pattern of SAM in the mid-latitudes ${ }^{49}$. With the warming climate there has been a concomitant reduction in precipitation (Fig. 3), soil and peat moisture, ice cap size, and snowfield permanence ${ }^{62}$ as well as marine nearshore productivity ${ }^{63}$. The diatom-based conductivity record reflects this change showing declining SHW strength beginning in the 1950s, as the SHW moves poleward (shown here as mean austral summer (DJF) jet latitude), and the core SHW belt and its associated storm tracks passes to the south of Marion Island ${ }^{49,64}$ (Fig. 3).

On longer centennial timescales, the spatial pattern of these changes (in SHW, temperature and rainfall) are consistent with a northward shift of the main belt of the SHW away from Antarctica during cool periods such as the LIA, and vice versa during the antecedent and more recent warm periods ${ }^{65}$. Mechanistic models of modern-day SHW behaviour show that warmer temperatures in the temperate latitudes cause the SHW to intensify and move poleward, as they do in austral summer months $(\mathrm{DJF})^{66}$. Conversely, flattened equatorial-pole temperature gradients result in weaker, northward deflected SHW, as seen in winter months (JJA). It has been hypothesised from paleoclimate records and models that over century- to millennialtimescales, the same principles should apply, with cooler extratropical temperatures resulting in weaker, more spatially diffuse and/or northward shifted winds, and warmer temperatures driving stronger winds closer around the Antarctic

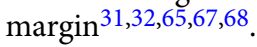

Few paleoclimate records from the high southern latitudes explicitly reconstruct SHW migration on centennial timescales. However, compilations of SHW and temperature records from the southern hemisphere continents and Antarctica reveal the likely impact of latitudinal shifts in the SHW and SAM modes (Fig. 4). For example, paleoclimate proxies from South African lake, cave, and marine records in the Winter Rainfall Zone (WRZ) suggest a link between SHW and shifting precipitation patterns over the last few millennia ${ }^{69}$. During the warm Medieval Climate Anomaly (MCA; 1000-1200 $\mathrm{CE}^{70}$ ), the SHW were well south of their present position, no longer impinging on the continent during winter ${ }^{69,71-73}$. However, with the onset of the LIA, WRZ precipitation increased with the northward migration of SHW-driven storm tracks ${ }^{50}$ (Fig. 4), resulting in the wettest climate of the late Holocene ${ }^{74}$. These patterns hold true in Australia and Southern South America as well, where record droughts were experienced during the MCA and cooler moister conditions prevailed during the LIA. However, concomitant changes to El Niño-Southern Oscillation (ENSO) and the Interdecadal Pacific Oscillation (IPO) make a clear attribution to the SHW in these regions difficult ${ }^{56,75}$.

In Antarctica, a wind strength record based on coarse aerosol particle deposition on the West Antarctic Ice Sheet also provides compelling evidence of a northward displacement of the SHW during the LIA and its reinvigoration at high latitudes in the last century (Fig. 4) ${ }^{68}$. Other Antarctic aerosol sea salt records similarly suggest a northward migration of the SHW (and shifts toward a negative SAM sign) between the MCA and the LIA, with an increasingly positive index beginning c. $1600 \mathrm{CE}$ resulting from the migration of the Subtropical Ridge ${ }^{65,76}$.

In this context, the Marion Island wind reconstruction provides an important bridge connecting inferred changes in the SHW events in the Antarctic with those from South America, South Africa, and Australia. Specifically, the combined evidence suggests that the centre of the core belt of the SHW passed through Marion Island on its migration north of the island at the beginning of the LIA, and south of the island beginning c 1950 $\mathrm{CE}$, the latter being confirmed by instrumental data.

Future scenarios. The apparent sensitivity of the SHW to relatively small $\left(1-2{ }^{\circ} \mathrm{C}\right)$ shifts in temperature presented here provides a basis for determining future wind and storm track migration and its implications for water security and drought severity on centennial timescales. This is especially relevant in the face of ongoing drought and wildfires currently affecting southern continental regions. Under future global and regional warming scenarios, the data suggest that the SHW will continue to intensify and shift poleward, thereby enhancing the severity of droughts that have already severely affected South Africa, SW Australia, and W Patagonia, and some sub-Antarctic islands ${ }^{20,23,49,77}$ as moisture-laden storm tracks shift further south with the core belt of the SHW. On Marion Island and other sub-Antarctic islands at similar latitudes, continued climate warming in the 21 st century will also likely enhance current warming and drying on the islands, as the core belt of the SHW bypasses the islands to the south, exacerbating ecological and glaciological changes already underway ${ }^{21,77}$.

Our data also confirm modelling results, which identify latitudinal shifts in the SHW over time with increased future warming ${ }^{78,79}$ and suggest that these relationships have persisted over centennial to millennial timescales ${ }^{31,67}$. The SHWtemperature relationship has important feedbacks on the climate system, not only on continental drought but also on atmospheric $\mathrm{CO}_{2}$ concentrations, and Antarctic Ice Sheet stability. Changes in the strength and location of the SHW have been linked to weakening of the Southern Ocean carbon sink both on multimillennial ${ }^{38}$ and recent instrumental timescales ${ }^{1,2}$. Hence, further strengthening of the winds from increasing temperatures will likely exert a positive feedback through the accumulation of more $\mathrm{CO}_{2}$ in the atmosphere. The SHW also influence ocean circulation, driving warmer water masses towards Antarctica leading to increased basal melting of ice shelves and ice sheet mass loss ${ }^{80-82}$. Future poleward-shifted and strengthened SHW will exacerbate this process, making already unstable ice shelves and the ice sheets they buttress increasingly susceptible to melting ${ }^{31}$.

\section{Methods}

Coring and dating. Marion Island is one of a small number of sub-Antarctic islands within the northern margin of the current core belt of the SHW. Sediment cores were collected from La Grange Kop $\left(46^{\circ} 56^{\prime} \mathrm{S}, 37^{\circ} 35^{\prime} \mathrm{E}\right)$, a small $\sim 1$ ha lake occupying a scoria cone on the western coast of Marion Island (Fig. 1). The lake is ideally positioned to accumulate sea salt and minerogenic inputs from the prevailing westerly winds (lake water conductivity $=170 \mu \mathrm{S} \mathrm{cm}^{-} 1$; see Supplementary Table 1), whilst receiving minimal inputs from elsewhere on the island (for a full site description see Supplementary Note 1).

Multiple cores were extracted from the deepest point of the basin ( $4 \mathrm{~m} \mathrm{depth}$ ) using a Livingston piston corer from paired inflatable boats. The flocculant uppermost sediments were retrieved using a UWITEC corer, which was extruded and subsampled at $0.5 \mathrm{~cm}$ intervals in the field. Cores were shipped and stored frozen.

Age determinations were made using ${ }^{14} \mathrm{C}$ radiometric methods on bulk organic sediments (Supplementary Table 3). Surface sediments yielded modern ages, suggesting the current absence of a radiocarbon reservoir effect. Surface sediments 
were dated using ${ }^{210} \mathrm{~Pb}$ and ${ }^{137} \mathrm{Cs}$, and the $\mathrm{CIC}$ method of age interpretation (see Supplementary Information). Age-depth models were generated using the software package BACON in $\mathrm{R}^{83}$.

Diatom-inferred conductivity. To reconstruct past sea salt aerosol inputs we developed a bespoke method to track past changes in lake water conductivity (which is a function of sea spray inputs) using diatom-based inference models. This utilises the strong statistical relationship between modern diatom species assemblages and lake water conductivity in 64 lakes on Marion Island ${ }^{40}$ and is applied as a transfer function (weighted averaging; $r^{2}=0.85$, RMSE $=0.06 \operatorname{log~mS~cm} \mathrm{cm}^{-1}$ ) to reconstruct past changes in conductivity from subfossil species assemblages preserved in the lake sediments (for more information on diatom species-environment transfer functions and model development see Supplementary Methods, Supplementary Table 2, Supplementary Figs. 5-7).

Diatoms were isolated from the sediments using standard oxidative techniques ${ }^{84}$ and mounted on plain glass coverslips using NAPHRAX mounting medium. Taxonomic assignments were made using reference literature ${ }^{42}$ and using the reference photographs to ensure consistency with the diatom-conductivity model and amongst sub-Antarctic island analysts. At least 400 valves were identified from each slide on an Olympus BX60 microscope at 1000× magnification and phase contrast under oil immersion.

Diatoms with $<1 \%$ in any one sample were excluded from further statistical analyses. PCA was performed on centred relative percentage diatom data from the lake using the software package rioja in $\mathrm{R}^{85}$. Diatom zones were delineated using constrained cluster analysis (CONISS ${ }^{86}$ ) and significance was assessed with the broken-stick model ${ }^{87}$.

Minerogenic inputs. An ITRAX micro x-ray fluorescence ( $\mu$-XRF) core scanner was used to track inputs of aerosols into the lake, focusing on sea salt and crustal elements in the cores. Fine-scale measurements of changes in bulk as-deposited (i.e., wet) sediment geochemistry was undertaken on flat half-core wet sediment surfaces using an ITRAX core scanner fitted with a Molybdenum (Mo) X-ray tube. $\mathrm{X}$-radiography settings were $50 \mathrm{kV}, 50 \mathrm{~mA}, 200 \mathrm{~ms} ; \mu$-XRF; Mo settings: $30 \mathrm{kV}$, $50 \mathrm{~mA}$, count time $10 \mathrm{~s}, 200 \mu \mathrm{m}$ or $2 \mathrm{~mm}$ interval with 50- or 5-point moving average for $1 \mathrm{~cm}$ subsample interval equivalence. Machine and sample calibration was undertaken using a synthetic glass standard and XRF fused glass discs from the core at the start and end of each core-site run. Raw count per second (cps) data were analysed using the Q-spec spectra matching software (Cox Analytical). As we were interested in primarily patterns of downcore variability, data are presented as total scatter-normalisation ratios and percentages of the total scatter-normalised sum, following established total-scatter normalisation procedures ${ }^{88,89}$ rather than equivalent whole-rock percentages. This avoids creating spurious values for elements that cannot be measured (e.g., $\mathrm{Na}, \mathrm{Mg}$ ) or have low count values (e.g., $\mathrm{Al}, \mathrm{Si}$ ) when using an ITRAX Mo-tube ${ }^{89}$. The uppermost sediments were flocculent and could not be preserved intact for scanning.

Proxies controlling for within lake influences. To understand changes in sedimentology whole core magnetic susceptibility (MS) (Bartington Instruments MS2G $1 \mathrm{~cm}$ loop sensor, $10 \mathrm{~s}$ ) was measured with a GEOTEK core logger using standard calibration procedures ${ }^{90}$. Biological changes were tracked using $\mathrm{C}, \mathrm{N}$, and $\delta^{13} \mathrm{C}$ analysis. Sediments were placed in $5 \% \mathrm{HCl}$ to remove any $\mathrm{CaCO}_{3}$ (assumed negligible), then washed over Whatman 41 filter papers with deionised water and dried at $40^{\circ} \mathrm{C}$ in a drying cabinet. When dry, samples were ground to a fine powder and stored in glass vials. Carbon isotope ratios $\left(\delta^{13} \mathrm{C}\right)$, percentage total organic carbon (\%TOC) and percentage total nitrogen (\%TN) were analysed during combustion in a Carlo Erba 1500 on<line to a VG Triple Trap and dual inlet mass spectrometer. $\delta^{13} \mathrm{C}$ values were converted to the VPDB scale using a within-run laboratory standard calibrated against NBS-19 and NBS-22, with C/N ratios calibrated against an Acetanilide standard. Replicate analysis of sample material indicated a precision of $\pm 0.1 \%$ for $\delta^{13} \mathrm{C}$ and \pm 0.1 for $\mathrm{C} / \mathrm{N}$.

\section{Data availability}

The datasets generated during and/or analysed during the current study are available in the UK Polar Data Centre repository (https://data.bas.ac.uk/metadata.php?id=GB/ NERC/BAS/PDC/01363). This paper contributes to PAGES2K Antarctica and to CLIVASH $2 \mathrm{~K}$.

Received: 4 March 2020; Accepted: 5 November 2020;

Published online: 09 December 2020

\section{References}

1. Le Quéré, C. et al. Saturation of the Southern Ocean $\mathrm{CO}_{2}$ sink due to recent climate change. Science 316, 1735-1738 (2007).

2. Hodgson, D. A. \& Sime, L. C. Palaeoclimate Southern westerlies and $\mathrm{CO}_{2}$. Nat. Geosci. 3, 666-667 (2010).
3. Landschützer, P. et al. The reinvigoration of the Southern Ocean carbon sink Science 349, 1221-1224 (2015).

4. Marshall, G. J., Orr, A., van Lipzig, N. P. M. \& King, J. C. The impact of a changing Southern Hemisphere Annular Mode on Antarctic Peninsula summer temperatures. J. Clim. 19, 5388-5404 (2006).

5. Pritchard, H. D. et al. Antarctic ice-sheet loss driven by basal melting of ice shelves. Nature 484, 502-505 (2012).

6. Gille, S. T. How ice shelves melt. Science 346, 1180-1181 (2014).

7. Smith, J. A. et al. Sub-ice-shelf sediments record history of twentieth-century retreat of Pine Island Glacier. Nature 541, 77-80 (2017)

8. Holland, P. R. et al. West Antarctic ice loss influenced by internal climate variability and anthropogenic forcing. Nat. Geosci. 12, 718-724 (2019).

9. Purich, A., Cai, W. J., England, M. H. \& Cowan, T. Evidence for link between modelled trends in Antarctic sea ice and underestimated westerly wind changes. Nat. Commun. 7, 10409 (2016).

10. Biastoch, A., Böning, C. W., Schwarzkopf, F. U. \& Lutjeharms, J. R. E. Increase in Agulhas leakage due to poleward shift in the southern hemisphere westerlies. Nature 462, 495-498 (2009).

11. Vaughan, D. G. et al. Recent rapid regional climate warming on the Antarctic Peninsula. Clim. Change 60, 243-274 (2003).

12. Turner, J. et al. Absence of 21 st century warming on Antarctic Peninsula consistent with natural variability. Nature 535, 411-415 (2016).

13. Siegert, M. et al. The Antarctic Peninsula Under a 1.5० C Global Warming Scenario. Front. Environ. Sci. 7, 102 (2019).

14. Marshall, G. J. Trends in the Southern Annular Mode from observations and reanalyses. J. Clim. 16, 4134-4143 (2003).

15. Haylock, M. R. et al. Trends in total and extreme South American rainfall in 1960-2000 and links with sea surface temperature. J. Clim. 19, 1490-1512 (2006).

16. Meneghini, B., Simmonds, I. \& Smith, I. N. Association between Australian rainfall and the Southern Annular Mode. Int. J. Climatol. 27, 109-121 (2007).

17. Abram, N. et al. Evolution of the Southern Annular Mode during the past millennium. Nat. Clim. Change 4, 564-569 (2014).

18. Ummenhofer, C. C. \& England, M. H. Interannual Extremes in New Zealand Precipitation Linked to Modes of Southern Hemisphere Climate Variability. J. Clim. 20, 5418-5440 (2007)

19. Ummenhofer, C. C., Gupta, A. \& England, M. H. Causes of Late TwentiethCentury Trends in New Zealand Precipitation. J. Clim. 22, 3-19 (2009).

20. Cai, W., Van Rensch, P., Borlace, S. \& Cowan, T. Does the Southern Annular Mode contribute to the persistence of the multidecade-long drought over southwest Western Australia? Geophys. Res. Lett. 38, L14712 (2011).

21. Reason, C. J. C. \& Rouault, M. Links between the Antarctic Oscillation and winter rainfall over western South Africa. Geophys. Res. Lett. 32, L07705 (2005).

22. Holz, A. et al. Southern Annular Mode drives multicentury wildfire activity in southern South America. Proc. Natl Acad. Sci. USA 114, 9552-9557 (2017).

23. Garreaud, R. D. Record-breaking climate anomalies lead to severe drought and environmental disruption in western Patagonia in 2016. Clim. Res. 74, 217-229 (2018).

24. Trenberth, K. E. et al. In Climate Change 2007. The Physical Science Basis. Contribution of WG 1 to the Fourth Assessment Report of the Intergovernmental Panel on Climate Change. (eds Solomon, S. et al.) 235-336 (Cambridge University Press, 2007).

25. Munro, D. R. et al. Recent evidence for a strengthening $\mathrm{CO}_{2}$ sink in the Southern Ocean from carbonate system measurements in the Drake Passage (2002-2015). Geophys. Res. Lett. 42, 7623-7630 (2015).

26. Mikaloff-Fletcher, S. E. An increasing carbon sink? Science 349, 1165 (2015)

27. Jones, J. M. et al. Assessing recent trends in high-latitude Southern Hemisphere surface climate. Nat. Clim. Change 6, 917-926 (2016).

28. Thompson, D. W. J. \& Solomon, S. Interpretation of recent Southern Hemisphere climate change. Science 296, 895-899 (2002).

29. Perlwitz, J., Pawson, S., Fogt, R. L., Nielsen, J. E. \& Neff, W. D. Impact of stratospheric ozone hole recovery on Antarctic climate. Geophys. Res. Lett. 35, L08714 (2008).

30. Thompson, D. W. J. et al. Signatures of the Antarctic ozone hole in Southern Hemisphere surface climate change. Nat. Geosci. 4, 741-749 (2011).

31. Mayewski, P. A. et al. Potential for Southern Hemisphere climate surprises. J. Quat. Sci. 30, 391-395 (2015)

32. Lamy, F. et al. Holocene changes in the position and intensity of the southern westerly wind belt. Nat. Geosci. 3, 695-699 (2010).

33. Bertrand, S., Hughen, K., Sepúlveda, J. \& Pantoja, S. Late Holocene covariability of the southern westerlies and sea surface temperature in Northern Chilean Patagonia. Quat. Sci. Rev. 105, 195-208 (2014).

34. Moreno, P. I. et al. Onset and Evolution of Southern Annular Mode-Like Changes at Centennial Timescale. Sci. Rep. 8, 3458 (2018). 
35. Stager, J. C. et al. Late Holocene precipitation variability in the summer rainfall region of South Africa. Quat. Sci. Rev. 67, 105-120 (2013).

36. Knudson, K. P., Hendy, I. L. \& Neil, H. L. Re-examining Southern Hemisphere westerly wind behavior: insights from a late Holocene precipitation reconstruction using New Zealand fjord sediments. Quat. Sci. Rev. 30, 3124-3138 (2011).

37. Hinojosa, J. L., Moy, C. M., Stirling, C. H., Wilson, G. S. \& Eglinton, T. I. A New Zealand perspective on centennial-scale Southern Hemisphere westerly wind shifts during the last two millennia. Quat. Sci. Rev. 172, 32-43 (2017).

38. Saunders, K. et al. Holocene dynamics of the Southern Hemisphere westerly winds and possible links to $\mathrm{CO}_{2}$ outgassing. Nat. Geosci. 11, 650-655 (2018).

39. Saunders, K. M., Hodgson, D. A., McMurtrie, S. \& Grosjean, M. A diatom-conductivity transfer function for reconstructing past changes in the Southern Hemisphere westerly winds over the Southern Ocean. J. Quat. Sci. 30, 464-477 (2015).

40. Van Nieuwenhuyze, W. Diatom species and limnological data from 64 lakes on subantarctic Marion Island (2011) (Version 1.0) [Data set]. (UK Polar Data Centre, Natural Environment Research Council, UK Research \& Innovation, 2020).

41. Heimburger, A., Losno, R., Triquet, S. \& Nguyen, E. B. Atmospheric deposition fluxes of 26 elements over the Southern Indian Ocean: Time series on Kerguelen and Crozet Islands. Global Biogeochem. Cycles 27, 440-449 (2013).

42. Van de Vijver, B., Frenot, Y. \& Beyens, L. Freshwater Diatoms from Île de la Possession (Crozet Archipelago, Subantarctica) (Gebrüder Borntraeger Verlagsbuchhandlung, 2002).

43. Marcott, S. A., Shakun, J. D., Clark, P. U. \& Mix, A. C. A reconstruction of regional and global temperature for the past 11,300 years. Science 339, 1198-1201 (2013).

44. Mann, M. E. et al. Global Signatures and Dynamical Origins of the Little Ice Age and Medieval Climate Anomaly. Science 326, 1256-1260 (2009).

45. Neukom, R. et al. Inter-hemispheric temperature variability over the past millennium. Nat. Clim. Change 4, 362-367 (2014).

46. PAGES2k Consortium. A global multiproxy database for temperature reconstructions of the Common Era. Sci. Data 4, 170088 (2017).

47. Tavernier, I. et al. Absence of a Medieval Climate Anomaly, Little Ice Age and twentieth century warming in Skarvsnes, Lützow Holm Bay, East Antarctica. Antarct. Sci. 26, 585-598 (2014).

48. Rouault, M., Melice, J. L., Reason, C. J. C. \& Lutijeharms, J. R. E. Climate variability at Marion Island, Southern Ocean, since 1960. J. Geophys. Res. Oceans 110, C5 (2005)

49. Gillett, N. P., Kell, T. D. \& Jones, P. D. Regional climate impacts of the Southern Annular Mode. Geophys. Res. Lett. 33, L23704 (2006).

50. Stager, J. C. et al. Precipitation variability in the winter rainfall zone of South Africa during the last $1400 \mathrm{yr}$ linked to the austral westerlies. Clim. Past 8, 877-887 (2012).

51. Fletcher, M. S. et al. Centennial-scale trends in the Southern Annular Mode revealed by hemisphere-wide fire and hydroclimatic trends over the past 2400 years. Geology 46, 363-366 (2018).

52. Xia, Z., Yu, Z. \& Loisel, J. Centennial-scale dynamics of the Southern Hemisphere westerly Winds across the Drake Passage over the past two millennia. Geology 46, 855-858 (2018)

53. Masiokas, M. H. et al. Glacier fluctuations in extratropical South America during the past 1000 years. Palaeogeogr. Palaeoclimatol. Palaeoecol. 281, 242-268 (2009).

54. Haberzettl, T. et al. Lateglacial and Holocene wet-dry cycles in southern Patagonia: chronology, sedimentology and geochemistry of a lacustrine record from Laguna Potrok Aike, Argentina. Holocene 17, 297-310 (2007).

55. Moy, C. M. et al. Isotopic evidence for hydrologic change related to the westerlies in SW Patagonia, Chile, during the last millennium. Quat. Sci. Rev. 27, 1335-1349 (2008).

56. Waldmann, N. et al. Holocene climatic fluctuations and positioning of the Southern Hemisphere westerlies in Tierra Del Fuego (54 $\mathrm{S})$, Patagonia. J. Quat. Sci. 25, 1063-1075 (2010).

57. Davies, B. J. et al. The evolution of the Patagonian Ice Sheet from 35 ka to the present day (PATICE). Earth Sci. Rev. 204, 103152 (2020).

58. Lorrey, A. et al. The Little Ice Age climate of New Zealand reconstructed from Southern Alps cirque glaciers: a synoptic type approach. Clim. Dyn. 42, 3039-3060 (2014).

59. Tibby, J. et al. Post little ice age drying of eastern Australia conflates understanding of early settlement impacts. Quat. Sci. Rev. 202, 45-52 (2018).

60. Gergis, J., Neukom, R., Gallant, A. J. E. \& Karoly, D. J. Australasian temperature reconstructions spanning the last millennium. J. Clim. 29 5365-5392 (2016).

61. Gille, S. T. Warming of the Southern Ocean since the 1950s. Science 295 1275-1277 (2002).

62. Le Roux, P. C. In The Prince Edward Islands: Land-Sea Interactions in a Changing Ecosystem, (eds Chown, S. F. \& Froneman, P. W.) 39-64 (Sun Press, 2008)

63. Allan, E. L. et al. Critical indirect effects of climate change on sub-Antarctic ecosystem functioning. Ecol. Evol. 3, 2994-3004 (2013).
64. Bracegirdle, T. Southern Hemisphere tropospheric westerly jet: 1979-present Polar Data Centre, Natural Environment Research Council, UK https://doi.org/ 10.5285/3952a4fe-683a-42e7-a074-bdec41c8ab16 (2018).

65. Goodwin, I. et al. A reconstruction of extratropical Indo-Pacific sea-level pressure patterns during the Medieval Climate Anomaly. Clim. Dyn. 43, 1197-1219 (2014)

66. Toggweiler, J. R., Russell, J. L. \& Carson, S. R. Midlatitude westerlies, atmospheric $\mathrm{CO}_{2}$, and climate change during the ice ages. Paleoceanography 21, PA2005 (2006).

67. Toggweiler, J. R. \& Russell, J. Ocean circulation in a warming climate. Nature 451, 286-288 (2008).

68. Koffman, B. G. et al. Centennial-scale variability of the Southern Hemisphere westerly wind belt in the eastern Pacific over the past two millennia. Clim. Past 10, 1125-1144 (2014).

69. Lüning, S. et al. Hydroclimate in Africa during the Medieval Climate Anomaly. Palaeogeogr. Palaeoclimatol. Palaeoecol. 495, 309-322 (2018).

70. Bradley, R. S., Hughes, M. \& Diaz, H. F. Climate in Medieval Time. Science 302, 404-405 (2003).

71. Hahn, A. et al. Holocene paleo-climatic record from the south African Namaqualand mudbelt: a source to sink approach. Quat. Int. 404, 121-135 (2016)

72. Zhao, $X$. et al. Holocene vegetation and climate variability in the winter and summer rainfall zones of South Africa. Holocene 26, 843-857 (2016).

73. Hahn, A. et al. Southern Hemisphere anticyclonic circulation drives oceanic and climatic conditions in late Holocene southernmost Africa. Clim. Past 13, 649-665, https://doi.org/10.5194/cp-13-649-2017 (2017).

74. Weldeab, S., Jan-Berend Stuut, R. R. \& Schneider, W. S. Holocene climate variability in the Winter Rainfall Zone of South Africa. Clim. Past $\mathbf{9}$, 2347-2364 (2013)

75. Vance, T. R., van Ommen, T. D., Curran, M. A. J., Plummer, C. T. \& Moy, A. D. A Millennial Proxy Record of ENSO and Eastern Australian Rainfall from the Law Dome Ice Core, East Antarctica. J. Clim. 26, 710-725 (2013).

76. Goodwin, I. D., van Ommen, T., Curran, M. \& Mayewski, P. A. Mid latitude climate variability in the south Indian and south-west Pacific regions since 1300 AD from the Law Dome ice core record. Clim. Dyn. 22, 783-794 (2004).

77. Favier, V. et al. Atmospheric drying as the main driver of dramatic glacier wastage in the southern Indian Ocean. Sci. Rep. 6, 32396 (2016).

78. Yin, J. H. A consistent poleward shift of the storm tracks in simulations of 21 st century climate. Geophys. Res. Lett. 32, L18701 (2005).

79. Fyfe, J. C., Saenko, O. A., Eby, M., Zickfeld, K. \& Weaver, A. J. The role of poleward-intensifying winds on Southern Ocean warming. J. Clim. 20, 5391-5400 (2007).

80. Thoma, M., Jenkins, A., Holland, D. \& Jacobs, S. Modeling Circumpolar Deep Water intrusions on the Amundsen Sea continental shelf, Antarctica. Geophys. Res. Lett. 35, L18602 (2008).

81. Assmann, K. M. et al. Variability of Circumpolar Deep Water transport onto the Amundsen Sea continental shelf through a shelf break trough. J. Geophys Res. 118, 6,603-6,620 (2013).

82. Hillenbrand, C.-D. et al. Grounding-line retreat of the West Antarctic Ice Sheet from inner Pine Island Bay. Geology 4, 35-38 (2013).

83. Blaauw, M. \& Christen, J. A. C. Flexible paleoclimate age-depth models using an autoregressive Gamma process. Bayesian Anal. 6, 457-474 (2011).

84. Renberg, I. A 12600 Year Perspective of the Acidification of Lilla-Öresjön, Southwest Sweden. Philos. Trans. R. Soc. B 327, 357-361 (1990).

85. Juggins, S. Rioja: Analysis of Quaternary Science Data (R package version (0.9 21)) http://cran.r-project.org/package=rioja (2017).

86. Grimm, E. C. CONISS - a Fortran-77 Program for Stratigraphically Constrained Cluster-Analysis by the Method of Incremental Sum of Squares. Comput. Geosci. 13, 13-35 (1987).

87. Bennett, K. D. Determination of the number of zones in a biostratigraphical sequence. New Phytolog. 132, 155-170 (1996).

88. Kylander, M. E., Ampel, L., Wohlfarth, B. \& Veres, D. High-resolution X-ray fluorescence core scanning analysis of Les Echets (France) sedimentary sequence: new insights from chemical proxies. J. Quat. Sci. 26, 109-117 (2011).

89. Davies, S. J., Lamb, H. F., \& Roberts, S. J. In Micro-XRF Studies of Sediment Cores: Applications of a Non-Destructive Tool for the Environmental Sciences (eds Croudace, I. W. \& Rothwell, R. G.) 189-226. (Springer, 2015).

90. Gunn, D. E. \& Best, A. I. A new automated non- destructive system for high resolution multi-sensor core logging of open sediment cores. Geo-Marine Lett. 18, 70-77 (1998).

91. SCAR MET READER Data https://legacy.bas.ac.uk/met/READER/ (2020)

92. Dätwyler, C. et al. Teleconnection stationarity, variability and trends of the Southern Annular Mode (SAM) during the last millennium. Clim. Dyn. 51, 2321-2339 (2018).

\section{Acknowledgements}

This project was funded by UK Natural Environment Research Council Grant NEK0045141 to DAH, a Research Foundation-Flanders travel bursary to EV, and an 
Antarctic Circumnavigation Expedition (ACE) grant from the Swiss Polar Institute. The research on Marion Island was facilitated by Prof. Steven Chown, University of Monash, Australia, with logistical support provided by the South African National Antarctic Programme. Bernard Coetzee, Mashudu Mashau, Rashawi Kgopong assisted with field sampling and Prof. Valdon Smith, John Cooper, Prof Marthán Bester and members of the M69 and M70 teams provided support and practical advice on Marion Island. Field sampling was supported by the South African Department of Environmental Affairs, permit $01 / 2013$.

\section{Author contributions}

The study was conceived and led by D.A.H., W.V., E.V., and B.B.P. Fieldwork was carried out by D.A.H., E.V., and W.V.N. Analytical work was performed by B.B.P. (chronology, diatoms, diatom-conductivity inference model, statistics), S.J.R. (micro-XRF, magnetic susceptibility), E.V. and W.V.N. (diatom species and environment data). B.B.P. wrote the manuscript and supplementary information with input from D.A.H. and additional contributions from S.J.R., L.S., W.V.N., E.V., W.V.

\section{Competing interests}

The authors declare no competing interests.

\section{Additional information}

Supplementary information is available for this paper at https://doi.org/10.1038/s43247020-00059-6.
Correspondence and requests for materials should be addressed to B.B.P.

Peer review information Primary handling editor: Joe Aslin.

Reprints and permission information is available at http://www.nature.com/reprints

Publisher's note Springer Nature remains neutral with regard to jurisdictional claims in published maps and institutional affiliations.

cc (i) Open Access This article is licensed under a Creative Commons Attribution 4.0 International License, which permits use, sharing, adaptation, distribution and reproduction in any medium or format, as long as you give appropriate credit to the original author(s) and the source, provide a link to the Creative Commons license, and indicate if changes were made. The images or other third party material in this article are included in the article's Creative Commons license, unless indicated otherwise in a credit line to the material. If material is not included in the article's Creative Commons license and your intended use is not permitted by statutory regulation or exceeds the permitted use, you will need to obtain permission directly from the copyright holder. To view a copy of this license, visit http://creativecommons.org/ licenses/by/4.0/.

(c) Crown 2020 